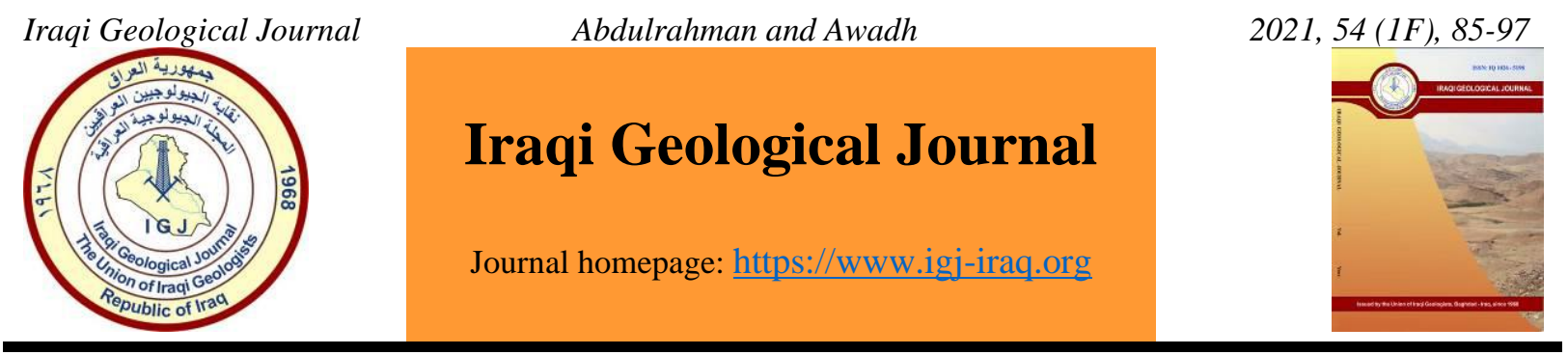

\title{
Depositional Environment of the Ibrahim Formation and Determining the Oligocene-Early Miocene Boundary in Eastern Iraq
}

\author{
Ameer Abdulrahman ${ }^{1, *}$ and Salih M. Awadh ${ }^{1}$ \\ ${ }^{1}$ Department of Geology, College of Science, University of Baghdad, Baghdad, Iraq \\ * Correspondence: ameerwaissey@yahoo.com
}

Received: 10 April 2021; Accepted: 2 June 2021; Published: 30 June 2021

\begin{abstract}
The aim of this study is to investigate the sedimentation environments and diagenetic processes of the Ibrahim Formation (Oligocene-early Miocene) in Zurbatiya, eastern Iraq. The Ibrahim Formation is comprised mostly of clayey micrite and skeletal grains composed of planktonic foraminifera, calcispheres, radiolaria, and benthic foraminifera. Glauconite and pyrite were documented in some restricted zones of this formation; they reflect quiet and reducing conditions. Radiolaria were identified in Late-Oligocene which was not known previously at this age regionally in carbonate formations of the Arabian Plate (AP). Mudstone, wackestone, and planktonic foraminiferal wackepackstone are the main microfacies that are affected by dissolution, cementation (granular), and replacement covering the age of the latest Eocene-Oligocene to the early-middle Miocene. Microfacies analysis indicates a basinal environment with a hemipelagic character of the deep shelf, toe-of-slope, and lower slope. Oligocene-Miocene outcrops have not been known previously in eastern Iraq although they have $160 \mathrm{~m}$ thick was first recorded in this study, whereas it was estimated as $56 \mathrm{~m}$ in the type section (well-1). Hence, the studied section is therefore suggested to be considered as a type section of the Ibrahim Formation. The Oligo-Miocene boundary is marked by restricted shallow-marine facies at the middle part of the formation indicating a short-term sea-level regression.
\end{abstract}

Keywords: Ibrahim Formation; Oligocene; Miocene; Basinal environment; Microfacies

\section{Introduction}

The Oligocene sequence in Iraq is consisted of nine formations (Shura, Sheikh Alas, Palani, Bajawan, Baba, Tarjil, Anah, Azkand, and Ibrahim formations) called the Kirkuk Group. The Oligocene succession was divided into the Early Oligocene age (Shura, Sheikh Alas, and Palani formations), the middle Oligocene (Bajawan, Baba, and Tarjil formations), and the late Oligocene which is includes Anah, Azkand, and Ibrahim formations (Al-Hashimi and Amer, 1986). The Oligocene succession is a complex reef system (back-reef, reef, and fore-reef) that had been developed in three cycles during the early, middle, and late Oligocene (Al-Kubaysi et al., 2014). The Oligocene basin has NW-SE trend in which the Ibrahim Formation is an important stratigraphic unit as it has oil productivity in northern oil fields in Iraq. It consists of globigerina marly limestone with granules of pyrite, occasional gluconate and planktonic micro Foraminifera (Jassim and Goff, 2006). The Oligocene is documented in the west and south of Mosul by Sissakian and Al-Jibouri (2012), and in western Iraq was studied Awadh and

DOI: $10.46717 /$ igj.54.1F.8ms-2021-06-28 
Hussien, 2015). Moreover, there are limited exposures in the north of Iraq. The Late Oligocene-Early Miocene boundary is marked by a major erosional unconformity (Al-Kubaysi et al., 2014; Sissakian et al., 2016). The study area is located in the eastern part of Iraq, within the Wasit governorate (Fig.1), and is determined by the coordinates shown in Table 1. This study was documented the Ibrahim Formation in eastern parts of Iraq and its relics along the thrust faults within the Himreen structure. It is characterized by several distinct lithologic subunits forming about $160 \mathrm{~m}$ thick (Fig.2). The main target of this study is to conclude the sedimentary environment and determine the Oligocene - Early Miocene boundary.

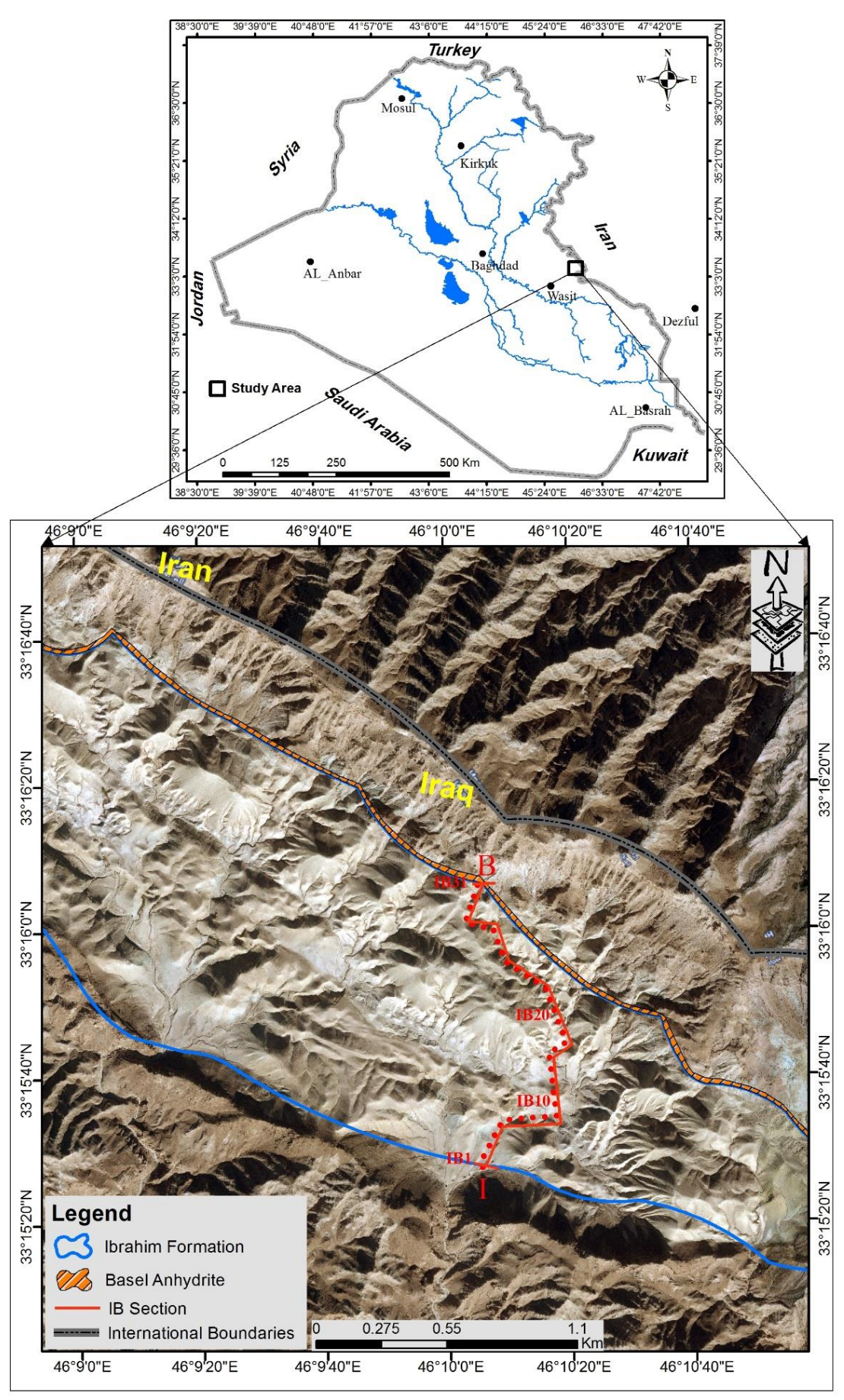

Fig. 1. The 3D Arial image shown the sampling sites on section IB of the Ibrahim Formation 
Table 1. The coordinates of the study area

\begin{tabular}{|c|c|}
\hline Easting & Northing \\
\hline $46^{\circ} 8^{\prime} \quad 45^{\prime \prime}$ & $33^{\circ} 16^{\prime} 55^{\prime \prime}$ \\
\hline $46^{\circ} 11^{\prime} 00^{\prime \prime}$ & $33^{\circ} 15^{\prime} 00^{\prime \prime}$ \\
\hline $46^{\circ} 8 \quad 45^{\prime \prime}$ & $33^{\circ} 15^{\prime} 00^{\prime \prime}$ \\
\hline $46^{\circ} 11^{\prime} 00^{\prime \prime}$ & $33^{\circ} 16^{\prime} 55^{\prime \prime}$ \\
\hline
\end{tabular}

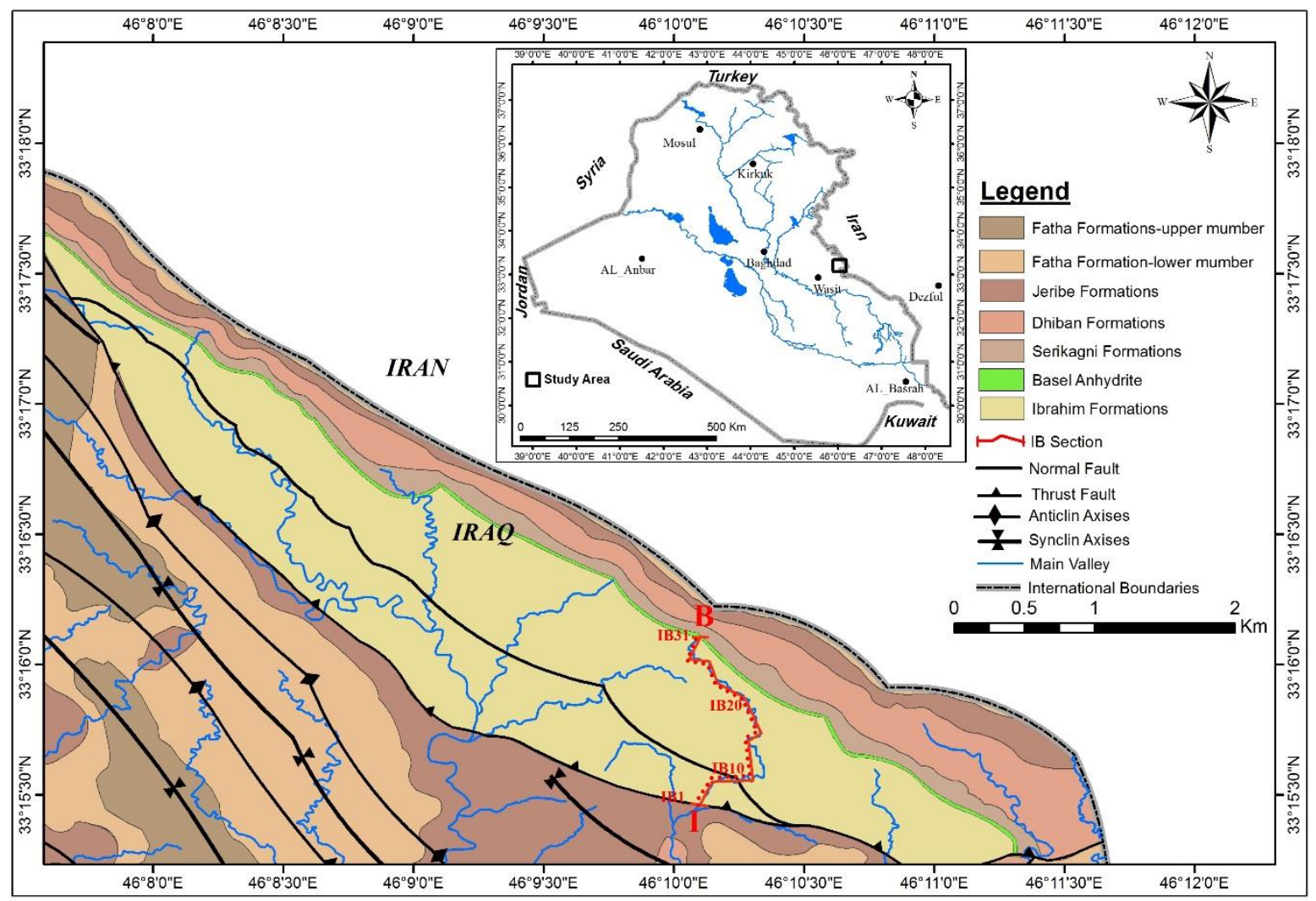

Fig. 2. Geological map of the study area shows the sampling sites on the IB section studied

\section{Material and Methods}

A total of 31 samples were collected from composite sections in the study area which represents the ideal strata of the center Kirkuk-Dezful basin (Fig. 3). Thin sections were made and stained with Alizarin red using Dickson's method (1965) for the criterion petrographic analyses to identify the mineralogy, textural (Calvet \& Tucker, 1988). The microfacies were analyzed based on Dunham (1962), Wilson (1975) and Flügel (2010).

\section{Geological Setting}

The Kirkuk Group belongs to the Latest Eocene-Recent tectonostratigraphic megasequence (AP11) (Sharland et al., 2004). During this epoch, the opening of the Neotethys and the development of the Paratethys, the collision of the AP with Eurasia plate with the north and east edges of the AP, and the development of the Zagros mountains had happened. The Megasequence located in the Foothill Zone in southeastern Iraq separated into two basins, Dezful-Kirkuk in the southeast and Mosul in Northwest. 
The Oligocene sediments are absent from most parts of the (AP) but are well-preserved in the north-eastern part and Iran. The Megasequence (AP11) as mentioned in Jassim and Goff (2006) is divided into the latest Eocene-Oligocene, early-middle Miocene, and the late Miocene-Recent. The Oligocene-Early Miocene Savian tectonic movement which influenced the Zagros suture was outstanding by the lifting of the Balambo-Tanjero Trough. It is possible, however, that some more internal parts of this zone which are now overthrusted, might have been invaded by a shallow sea during the Early Miocene. The Ibrahim formation is a tranzition for two sub-cycles, the Latest Eocene-Oligocene, and early middle Miocene composing mainly of alternative marl and marly limestone underlying the marker bed (Basal anhydrite) (Jassim and Goff, 2006; Aqrawi et al., 2010). It is comprised of $56 \mathrm{~m}$ of globigerina marly limestone with patches of pyrite and gluconite, and fauna of planktonic foraminifera precipitated in a basinal environment during the late Oligocene (Jassim \& Goff, 2006).

\begin{tabular}{|c|c|c|c|c|c|c|}
\hline Era & Age & Fn. & S. NO. & Thickness (m) & Lithology & Description \\
\hline 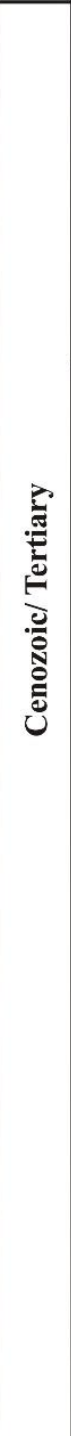 & 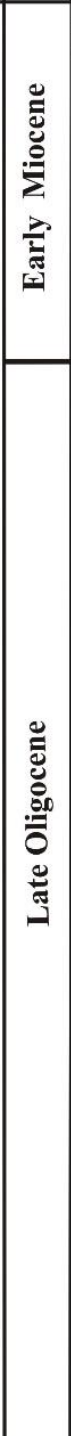 & 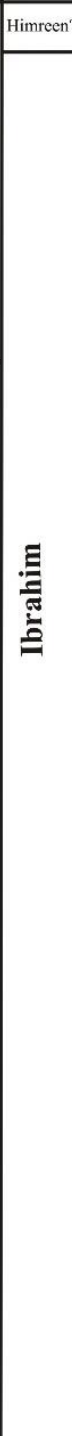 & $\begin{array}{l}\text { IB31 } \\
\text { IB30 } \\
\text { IB29 } \\
\text { IB28 } \\
\text { IB27 } \\
\text { IB26 } \\
\text { IB25 } \\
\text { IB24 } \\
\text { IB23 } \\
\text { IB22 } \\
\text { IB21 } \\
\text { BB20 } \\
\text { IB19 } \\
\text { IB18 } \\
\text { IB17 } \\
\text { IB16 } \\
\text { IB15 } \\
\text { IB14 } \\
\text { IB13 } \\
\text { IB12 }\end{array}$ & $\begin{array}{l}160- \\
140- \\
120- \\
80-\end{array}$ &  & $\begin{array}{l}\text { Marly limestone: Olive in color, medium tough, thick } \\
\text { bed, sharp contact, } \\
\text { Marly limestone: grey in color, tough, thick bed, sharp } \\
\text { contact. } \\
\text { Sandy limestone: brownish grey in color, tough, sharp } \\
\text { contact. } \\
\text { Interbedded Marl and Marly limestone: pale gray in } \\
\text { color, tough, thick bed. } \\
\text { Marl: Olive in color, medium tough, massive, slope } \\
\text { forming. }\end{array}$ \\
\hline
\end{tabular}

Fig. 3. Stratigraphic column and field description of the ideal strata of the Ibrahim Formation at center of Kirkuk Dezful basin 


\section{Results}

The Ibrahim Formation consists of several distinct lithologic subunits forming about $160 \mathrm{~m}$ thick (Fig. 3). It is exposed as traces along thrust faults within a part of the Hamrin structure in the study area (Fig.2). The basinal anhydrite rests directly and conformably on the Ibrahim formation ( Aqrawi et al., 2010). However, the upper contact is conformably composed of basal anhydrite, while the lower contact is obscured.

The bottom layer (20m thick) of the Ibrahim Formation is characterized by an olive color and consisted of thick beds to massive, medium to tough with a conchoidal fracture, follows this layer a thick bade of marly limestone (17 $\mathrm{m}$ thick), this layer is followed by a layer of sandy limestone ( $3 \mathrm{~m}$ thick) brown to gray color, and tough, follows this layer a layer composed of marly limestone, olive to gray color, medium to thickly bedded, (15 m thick) it represents the top of the lower part. The middle part (55m thick) appears as isolated hills in the study area, friable materials composed of thick beds of shaly limestone. At the base of the upper part ( $20 \mathrm{~m}$ thick) an alternation of marl with marly limestone of green to dark gray color. The top layer of the formation (30m thick) is dominant by marl, greenish gray color, and friable massive bed (Fig. 3). Three microfacies types are recognized in the Ibrahim Formation within the study area using classification stated by Embry \& Klovan (1971) that was modified from Dunham, (1962), Wilson, (1975) and Flügel, (2010). All these standard facies is illustrated in Fig. 4. Various features and textures were identified based on Scholle \& Ulmer-Scholle (2003) and Flügel (2010). The important note is that the original textures was well preserved.

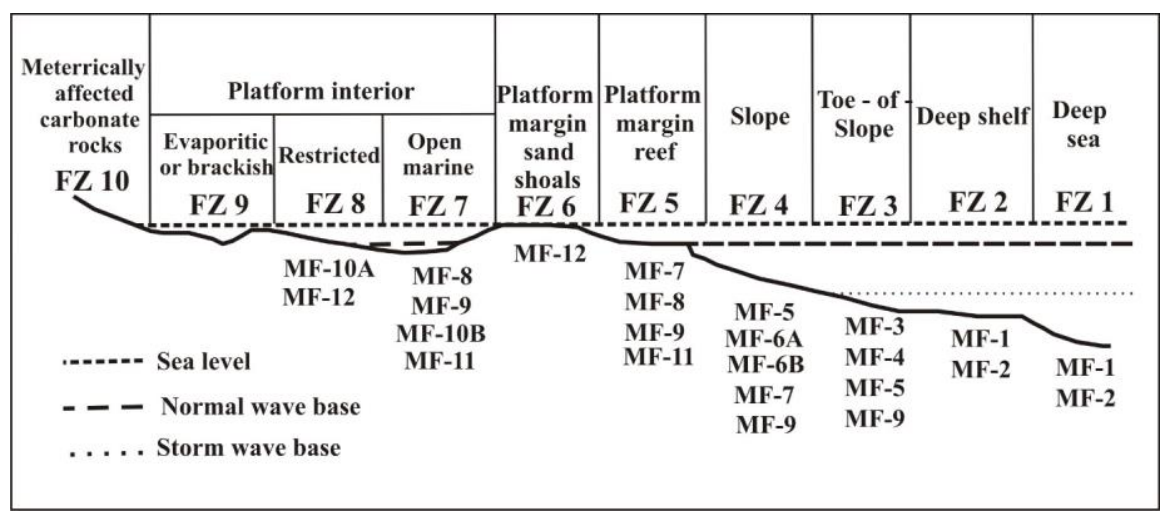

Fig. 4. Standard microfacies after Wilson (1975) and Flügel ( 2010)

\subsection{Skeletal Grains}

The skeletal grains are either fragments or complete shells and the remnants or excrement of organisms. Their size varied from $0.05 \mathrm{~mm}$ to several centimeters. The skeletal grains are consisted of calcite, high and low Mg - calcite, aragonite, and may be silica (Flügel, 2010). The identified skeletal grains in the Ibrahim Formation are mainly composed of planktonic foraminifera, calcispheres, radiolaria, and to a lesser extent benthic foraminifer and bioclasts.

\subsubsection{Planktonic foraminifera}

The fauna is identified with varied Planktonic forams such as Globorotalia kugleri sp., which is dominant in the formation. Krasheninnikov (1973) had considered this species as adopted as the index fossils to the lower boundary of Neogene, while Kennett \& Srinivasan (1983) stated that this species indicates a tropic climate of the early Miocene. Globigerinoides are extensively used to determine and to find out the paleoceanography and paleoclimate. Spezzaferri et al. (2018) mention that their avialibility 
during the Neogene has been used for biochronology as the first appearance was at the Oligocene-Miocene (Plate 1A and B and Plate 2C, D and E). Globigerina binaiensis sp, the genus is an important as it intergraded in the late Oligocene and early Miocene (Wade et al., 2018). The Miocene-Oligocene boundary was identified by samples IB25 to IB27 located at the upper part of the middle of the Ibrahim Formation (Plate 2C and D).

\subsubsection{Calcispheres}

Calcispheresaare is usually denoted as hollow, spherical calcareous microfossils of various origins (Berkyová and Munnecke, 2010). Calcispheres of various origin linked to a nutrient-rich, well-sheltered (Berkyová and Munnecke, 2010). Munnecke et al (2008) and Servais et al (2009) had described calcispheres as probably planktonic organisms of unknown origin. However, calcispheres are mostly associated with an open shelf to ocean pelagic deposits (Scholle and Ulmer-Scholle, 2003). In the present study, calcispheres are abundant and exist in most of the formation. The calcispheres have different sizes and regularly thick of wall consisting of fine granular (micritic) calcite, and sometimes sparite (Plate 1C and D).

\subsubsection{Radiolaria}

Neogene radiolaria fauna has been used to reconstructed environmental changes such as paleotemperature, sea level, and marine productivity, which are the primary controlling factors of evolution (Kamikuri et al., 2009). In the present study, radiolarian assemblage as interval occurrence, which is the first appearance in base, two intervals at the top of the middle part of the succession. (Plate 1, D and Plate 2, A and D).

\subsubsection{Benthonic foraminifera}

Benthic species have been used in paleoceanographic reconstructions (Gooday and Alve, 2001). Benthic foraminifera were identified as a small in size. Textularia $\mathrm{sp}$ is the dominant species assemblage, whereas the rear assemblage is Rotalia sp. Benthic species are successfully used for the analysis of bathymetry of sediments. Abundant pelagic foraminifera represents a more pelagic, deep offshore environment (Mateu-Vicens et al., 2008). The benthonic foraminifera species occur in the mudstone facies suggesting quiet and restricted shallow marine environments (Plate 1E, F and Plate 2B).

\subsection{Non-skeletal Grains}

Chert, glauconite, and pyrite are the main non-skeletal grains.

\subsection{Microfacies Type}

The microfacies of carbonates of different ages can be classified into main types reflecting the sedimentary and environmental conditions in a specific sedimentary environment with associated sedimentological datum (Flügel, 2010). Three microfacies types are recognized in the Ibrahim Formation, as following:

\subsubsection{Mudstone microfacies}

These microfacies are varicolored (pale grey and brownish-grey), tough, consist of few skeletal grains less than $10 \%$, benthic, calcispheres, and planktonic forams. It is divided into the following submicrofacies: Planktonic foraminiferal lime mudstone, laminated mudstone, and bioclastic mudstone. All these are slightly affected by the diagenetic processes. The mud matrix consists of micritic calcite. 
Benthic lime mudstone microfacies are equivalent to the (SMF-3) Standard Microfacies (Wilsons, 1975), which belongs to (FZ-3) suggesting a deep-sea, low energy environment while bioclastic calcareous mudstone reflects restricted shallow-marine and low-energy( SMF-3).

\subsubsection{Benthic foraminiferal lime mudstone}

The microfacies in the middle parts consists of less than $10 \%$ skeletal grains. The groundmass is essentially micritic calcite admixed with siliciclastic clay, which is slightly affected by diagenetic processes like cementation, and dissolution. Benthic foraminifera is recognized as the main skeletal grains such as Textularia $s p$ as shell fragments, submerged in muddy ground. The benthic foraminiferal lime mudstone microfacies are equivalent to the (SMF-1) Standard Microfacies (Wilsons, 1975). It represents deposition at (FZ1) that is a deep-sea and basinal setting. Samples (IB15- IB16) and (IB21-IB23), (Plate 1, E), (Fig. 5).

\subsubsection{Bioclastic mudstone}

This microfacies is found in the middle and upper parts with a color of dark grey to grey. The groundmass is consisted of very fine to fine crystalline calcite and matrix composition (more than 90\%), with benthic foraminiferal species such as Textularia sp, Rotalia sp. These facies have less effect by diagenetic processes. This microfacies indicate changes from open-marine to shallower marine environment with low-energy. It is equivalent to the SMF-3 Standard Microfacies of Wilsons (1975). (Plate 2B). Samples (IB15-IB17) and (IB29-IB31), (Fig. 5).

\subsubsection{Wackestone microfacies}

This microfacies is common facies has skeletal component up to $15 \%$, planktonic, Radiolaria, calcispheres forms and small benthic foraminifera. The groundmass is micrite mixed with siliciclastic and several non-carbonate such as, pyrite, and glauconite. Wackestone is widely distributed in the Ibrahim Formation showing basinal and lower slope environments. Wackestone microfacies include each of the following submicrofacies.

\subsubsection{Planktonic wackestone}

This facies is a common, characterized by predominant grains about $(10 \%-45 \%)$, from rocks component total, with abundant planktonic foraminifera, calcispheres, and very rare benthic foraminifera. The groundmass content of the admixed of siliciclastic and calcite micrite, it brown to grey. This facies was affected by diagenetic processes such as dissolution and equivalent to the (SMF-1) Standard Microfacies (Wilsons, 1975) which belongs to Facies Zones (FZ-1) indicating a deep-sea, Sample (IB24- IB28) in Plate 1, C, and D, (Fig. 5).

\subsubsection{Radiolaria wackestone}

This facies consists of granules about (12\% - 43\%), from components total of the rock, and the percentage of radiolaria and planktonic foraminifera (including calcispheres with little bioclast and small foraminifera (Rotalia and Textularia). The groundmass is micrite admixed with siliciclastic with light to dark brown. This facies is equivalent to Wilson's (1975) Standard Microfacies (SMF-1) which belongs to Facies Zones (FZ-1) described deep sea. Sample (IB11 - IB14) (Plate 2A, C and D), (Fig. 5).

\subsubsection{Planktonic foraminiferal wackepackstone}

These microfacies is mainly contained radiolaria, planktonic foraminifera, and benthic foraminifera at the base of the formation. It is highly fossiliferous. The skeletal grains are composed of 
approximately $50 \%$, converted to $70 \%$ packstone. Most of the components are Planktonic foraminifera and Radiolaria, with little benthic forams of Textularia sp and Rotalia sp and shell fragments. The groundmass is micrite of calcite admixed with siliciclastic. Planktonic foraminiferal wackepackstone facies are equivalent to the SMF-2 Standard Microfacies of Wilsons (1975) indivates a deposition a deep shelf (FZ 2) (Sample IB1 to IB10) (Plate 1A, and B) and (Plate 2E, and F), (Fig. 5).

Table 2. Description of the main facies and depositional environment (DE) of the Ibrahim Formation

\begin{tabular}{|c|c|c|c|}
\hline Main facies & Characteristics & $\overline{\text { DE }}$ & S. No \\
\hline Bioclastic mudstone & Benthic foraminiferal species & Restricted shallow-marine & IB29-IB31 \\
\hline Planktonic wackestone & Radiolaria and planktonic foraminifera & $\begin{array}{l}\text { Slope, deep shelf, and basinal } \\
\text { setting }\end{array}$ & IB24-IB28 \\
\hline $\begin{array}{l}\text { Benthic foraminiferal lime } \\
\text { mudstone }\end{array}$ & planktonic foraminifera & deep sea and basinal setting & IB21-IB23 \\
\hline Bioclastic mudstone & Benthic foraminiferal species & Restricted shallow-marine & IB17-IB20 \\
\hline $\begin{array}{l}\text { Benthic foraminiferal lime } \\
\text { mudstone }\end{array}$ & Trace-fossil and shell fragments & Restricted shallow-marine & IB15-IB16 \\
\hline Radiolaria wackestone & $\begin{array}{l}\text { Radiolaria, planktonic foraminifera, } \\
\text { and benthic foraminifera }\end{array}$ & $\begin{array}{l}\text { Slope, deep shelf, and basinal } \\
\text { setting }\end{array}$ & IB11-IB14 \\
\hline $\begin{array}{l}\text { Planktonik foraminiferal } \\
\text { wakepakston }\end{array}$ & $\begin{array}{l}\text { Radiolaria and planktonic forms and } \\
\text { benthic foraminifera }\end{array}$ & $\begin{array}{l}\text { Slope, deep shelf, and basinal } \\
\text { setting }\end{array}$ & IB1-IB10 \\
\hline
\end{tabular}

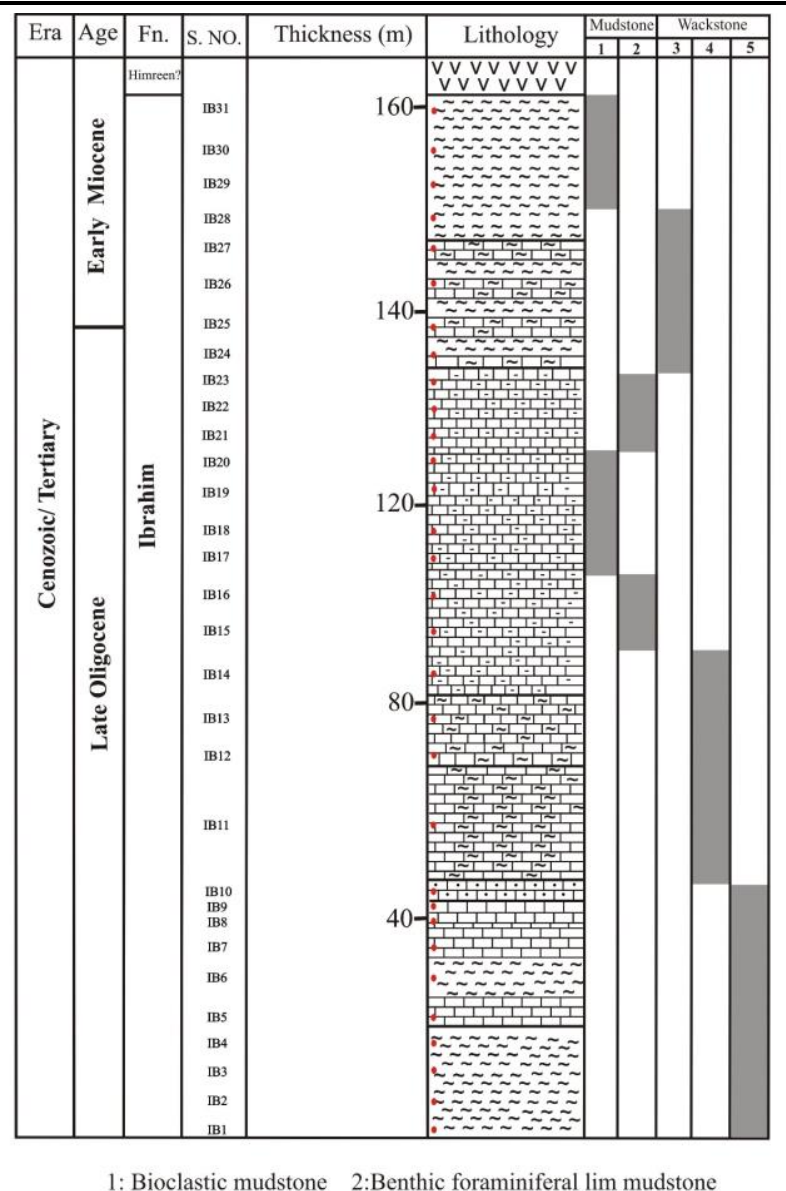

3: Planktonic wackstone 4:Radiolaria wackstone 5 :Planktonic foraminiferal wackstone

Fig. 5. Microfacies interpretation of the stratigraphic column of the Ibrahim Formation 

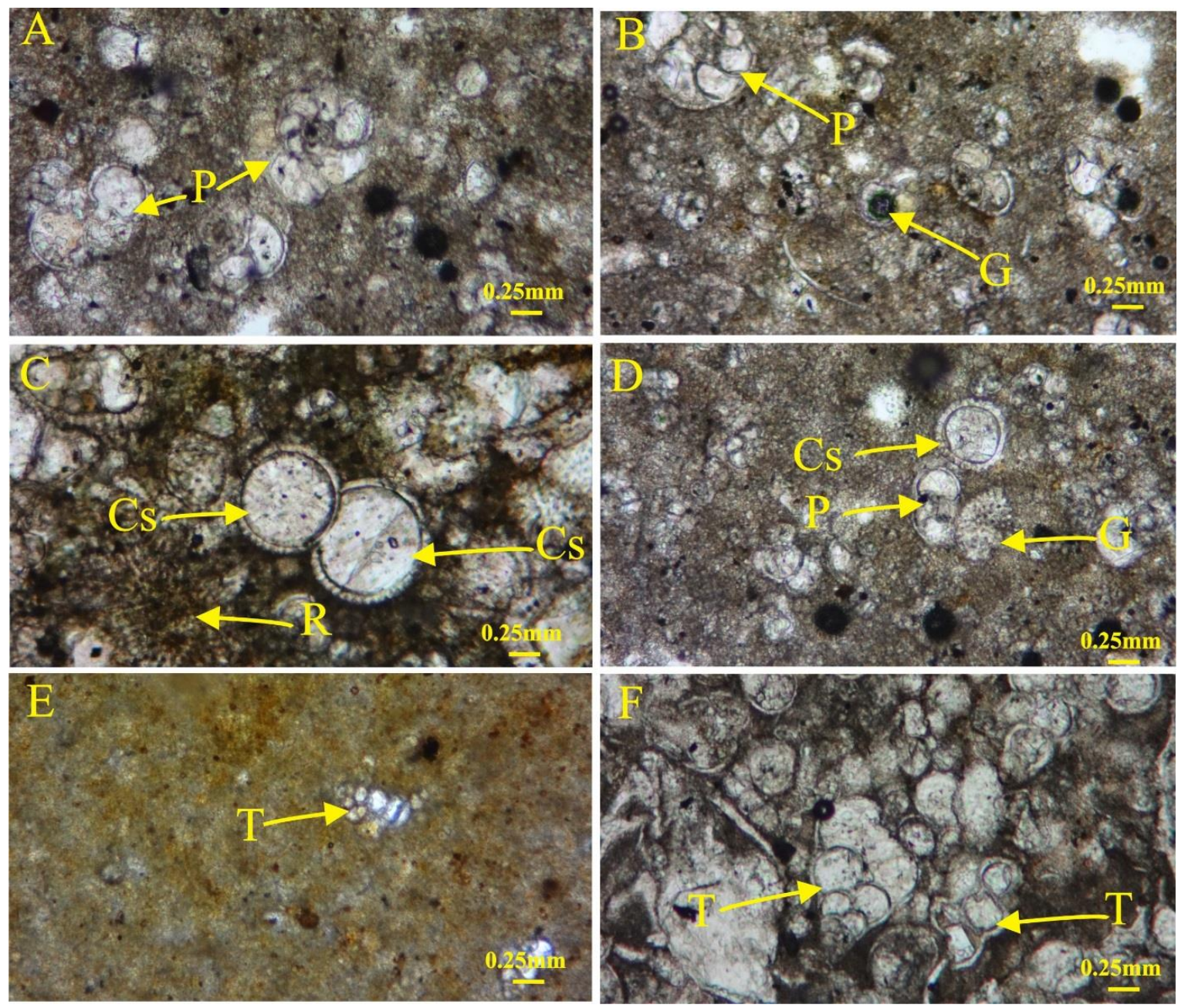

Plate 1. A and B: Planktonic foraminifera (p), Globorotalia kugler SP in wackepackstone facies, S.No. IB9 and IB10 respectively; C and D: Calcispheres (Cs) and radiolarian (R), wackstone facies, S.No. IB24 and IB28; E and F: Benthonic Foraminifera, Textularia sp (T) in mudstone and wackepackstone, S. No. IB15 and IB1 respectively. All samples were examined under polarized light with a lens 10X.

\subsection{Diagenesis}

Dissolution and cementation are the main diagenetic events that influenced the sediments of the Ibrahim Formation. Replacement is less affacted sediments. The majority of these processes are early diagenetic and reflected shallow-marine burial environments. Dissolution is generally characterized by fabric selective dissolution represented by molding of skeletal grains (Plate 3A). Cementation occurs as a result of the precipitation of minerals inside the primary or secondary pores and requires that the pore fluids be saturated with these minerals (Flugel, 2004). This process is common in carbonate rocks, it may take place soon after depositional at any late time. The samples have been cemented by calcite as drusy cement, this type is common in the studied carbonates and represented by subhedral to euhedral crystals, ranges in size from 10 to $60 \mu \mathrm{m}$, filling molds (Plate 3B and C). Replacement is an allochemical constructive diagenesis involves calcification of aragonite (Plate 3B and C) and/or partially replaced by other minerals like phosphate pyrite and glauconite (Plate 3D, E and F) respectively, it can be seen in most of the samples. 

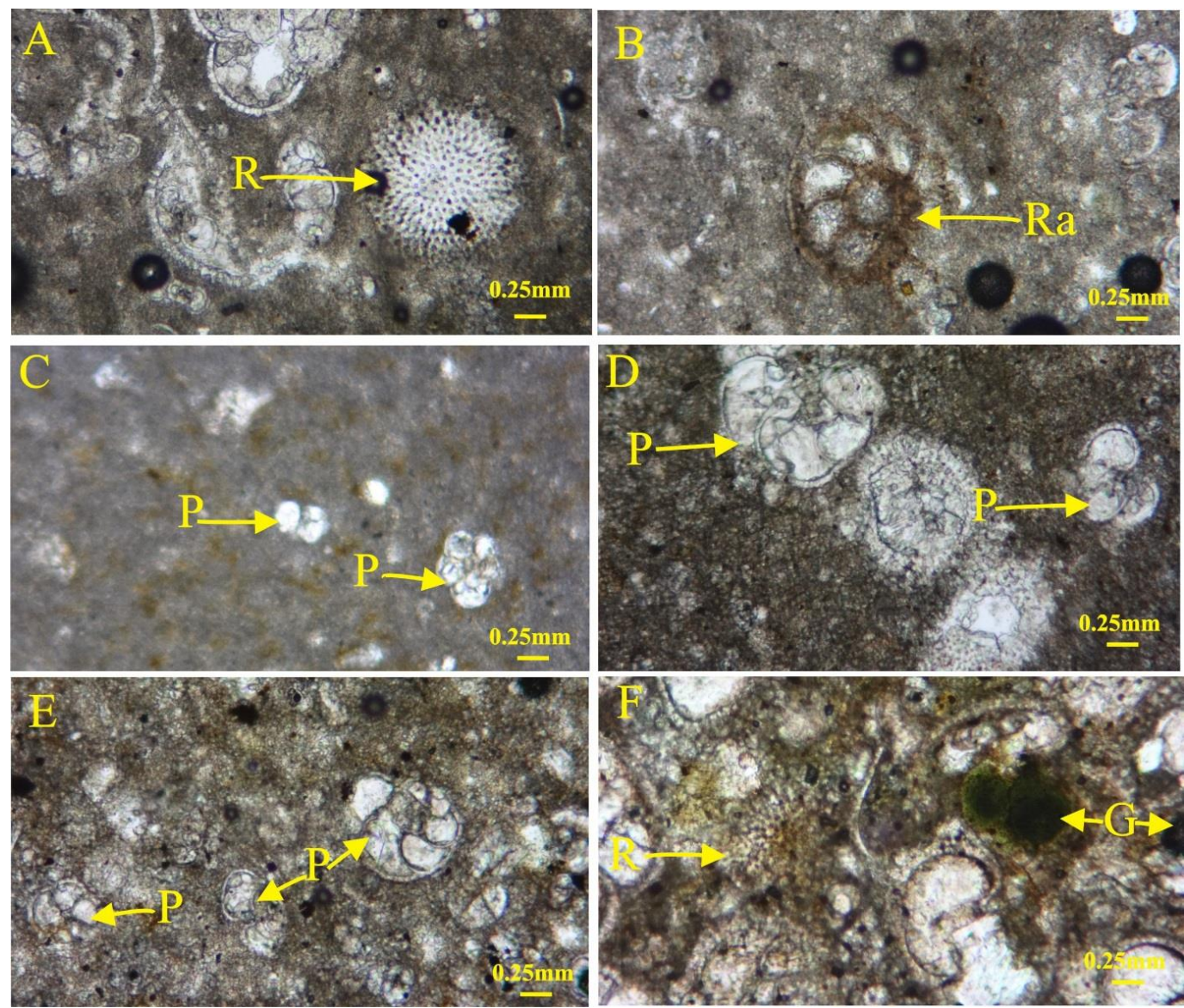

Plate 2. A: Radiolaria (R), in wackestone facies, S.No IB11; B: Benthonic Foraminifera Rotalia sp (Ra), in mudstone facies, S.No IB30; C and D: Planktonic foraminifera (P), Globigerina binaiensis, wackestone facies,

S.No. IB 25 and IB 27 respectively; E) Planktonic foraminifera (P), Globigerinoides with olive glauconite Wackepackstone facies, IB2; F: Glauconite (G) green color and observed Radiolaria (R), Wackepackstone facies, S.No. IB 9. All samples were examined under polarized light with a lens $10 X$.

\section{Discussion}

In the easternmost part of Iraq, the Oligocene-Miocene age are not previously known to crop out in the area, whereas in nearby areas only Middle-Late Miocene represent by the Fatha, Anjana, and Mukdadiya formations are exposed. The previous authors have not mentioned the Oligocene rocks in the studied. However, recently, the area was studied by Geosurve Iraq to draw a detailed geological map (1:25 000) in 2013 - 2016. The Latest Oligo-Miocene age in northern Iraq has been observed unconformity (Al-Kubaysi et al., 2014;). The succession comprises about $160 \mathrm{~m}$ of marly limestones and marl, with faunal assemblages and diversified Planktonic forams with the interval of radiolaria and rare benthic forams. The age of the formation is of critical importance for the evaluation of the Kirkuk-Dezeful basin. The main biogenic components of the Ibrahim Formation are planktonic foraminifera, radiolaria, calcispheres, and benthic foraminifera. Krasheninnikov (1978) considered Globorotalia kugleri sp., which is found throughout the formation, as the index fossils to lower boundary of Neogene.(Kennett and Srinivasan, 1983) state that this species appears only in the tropics of the early Miocene. Globigerina binaiensis sp., This genus is important because they are intergraded in the late Oligocene. It's absent in the upper part of the succession. The presence of Globorotalia kugleri sp. in most of the samples and the absence of Globigerina binaiensis indicates transitional between two cycles of Megasequence AP11, latest Eocene-Oligocene, and Early-Middle Miocene. Calcispheres can usually define as hollow calcareous spherical shapes microfossils of different origins, (Berkyová \& 
Munnecke, 2010). In the present study, calcispheres are plenty with other planktonic and appear in most of the formation. These calcispheres have varied sizes and moderately thick walls composed. Calcispheres are associated mainly with an open shelf to ocean pelagic deposits; (Scholle \& Ulmer-Scholle, 2003). According to Apel et al. (2002).
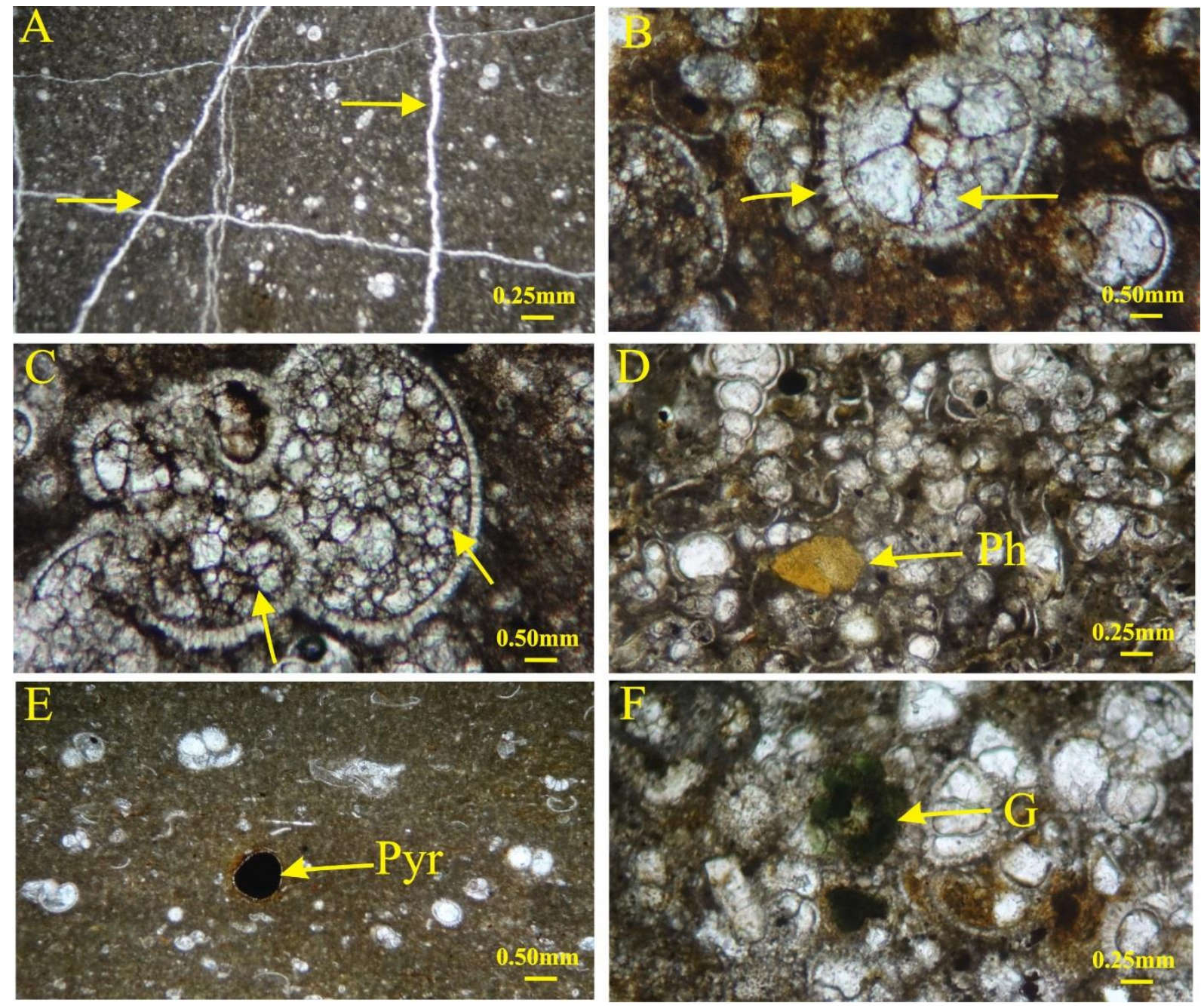

Plate 3. A. Dissolution processes, fabric selective represented by molding of skeletal grains, IB25 and IB24; B and C: Cementation of granular calcite and replacement forming calcification, IB 5 and IB4; D: skeletal grain replacement partially by phosphate $(\mathrm{Ph})$; E: A chamber of fossils filled with pyrite (pyr); F: skeletal grain replacement partially by glauconite (G). All samples were examined under polarized light with a lens $10 \mathrm{X}$.

Global calcisphere bio event associated with OAE (Ocean Anoxic Event). Because there are common appearances in all samples, suggesting reduction conditions during the depositional time. Radiolaria have been employed with great success in studies of climate change, in biostratigraphic dating of both Cenozoic deep-sea sediments and more ancient sedimentary rocks, often in metamorphosed tectonic terranes, and in studies of evolutionary processes, Radiolaria preservation linked to productivity triggered by climatic cooling during the early Oligocene, ( Zachos et al., 1999, and Apel et al., 2002). In this study, the radiolaria faunal change was documented as well as intervals of their appearance about the outstanding climate cooling. Modernistic radiolarians are considerable in deep-sea deposits, especially in Pacific equatorial regions. The accumulation of radiolarian mud in the high latitude regions indicates deposition at great depths (Flügel, 2010). As a result of the difference in temperature between the polar regions and the tropics, an intra-oceanic current is produced that significantly supplies nutrients (Kennett, 1977). Radiolaria and spread are in parallel with nutrients 
supplies (Apel et al., 2002). Radiolaria is affected by nutrients and the amount of sediments, so its abundance increases with depth in any sedimentary basin (Empson, 1984). In the current study, Radiolaria clusters refer to the change in sea level in response to the that tectonics or perhaps cooling seawater and the upwelling controls the sedimentary basin. This is evident by the radiolaria clusters at the bottom of the formation (samples IB1- IB 14) and at the middle part of the formation (samples IB21-IB28). The radiolaria are well preserved, because they were slightly affected by the dissolution processes rather than another interval. This indicate a deep environment with acidic $\mathrm{pH}$. Calcification of radiolaria is also noticed, it starts during the early diagenetic stage and it continues through the first stages of the burial. The calcification of radiolaria is a common process in limestones and the radiolarian crusts are replaced by calcite (Daoud et al., 2010). Microfacies are indicative of the deep marine environment. Planktonic wackestone and mud-wackestone is the most abundant microfacies type in the formation, within an interval of radiolarian wackestone, which is distributed through the different level in the studied succession, reflecting highest deepening in a quiet depositional environment. The bioclastic calcareous mudstone facies indicate a shift to more restricted conditions with normal marine of low-energy. According to the microfacies analyses and petrography, the I brahim Formation was deposited in a deep-sea outer shelf.

\section{Conclusions}

Based on the radiolaria and the mine microfacies, it is evident that the sedimentary basin of the Ibrahem Formation was affected by tectonics, which affected the sedimentation environment in the transition from the deep environment (the lower part of the formation and upper of the middle part) to the continental shelf environment twice. The fossil data (Globigerina binaiensis sp.) indicate that the Miocene-Oligocene boundary is in the upper of the middle part marked by samples IB25. The distribution of calcispheres indicates a deep hypoxic reductive environment.

\section{Acknowledgements}

We are grateful to the Laboratory staff of the Iraqi Geological Survey in making the thin sections. We would also like to express our thanks and appreciation to Basma Al-Samarrai, Mustafa Asaad for their assistance. The authors are very grateful to the Editor in Chief Prof. Dr. Salih M. Awadh, the Secretary of Journal Mr. Samir R. Hijab and the Technical Editors for their great efforts and valuable comments.

\section{References}

Al-Hashimi, H. A. J., Amer, R. M., 1986. Restudy of the Ibrahim Formation in the type section, Ibrahim well no. 1, Mosul area, N. Iraq. Journal of the Geological Society of Iraq, 19(3), 93-100.

Al-Kubaysi, K. N., Sissakian, V. K., Karim, S. A., 2014. Stratigraphy of the Oligocene-Early Miocene exposed formations in Sinjar area, NW Iraq. Iraqi Bulletin of Geology and Mining, 10 (3), 1- 28.

Apel, M., Kiessling, W., Böhm, F., Lazarus, D., 2002. Radiolarian faunal characteristics in Oligocene of the Kerguelen Plateau, Leg 183, Site 1138', in Proceedings of the Ocean Drilling Program: Scientific Results. Texas A \& M University, 1-48.

Aqrawi, A. A., M. Mahdi, T.A., Sherwani, G.H., Horbury, A.D., 2010. Characterization of the midCretaceous Mishrif reservoir of the southern Mesopotamian Basin, Iraq. American Association of Petroleum Geologists Conference and Exhibition, 7-10.

Awadh, S. M., Hussien, S. A., 2015. Rare earth elements geochemistry of the Upper Oligocene-Middle Miocene Succession in the Western Iraq. Iraqi Journal of Science, 56(4C), 3487-3496.

Berkyová, S., Munnecke, A., 2010. Calcispheres as a source of lime mud and peloids evidence from the Early Middle Devonian of the Prague Basin, the Czech Republic. Bulletin of Geosciences, 85(4), 585-602. 
Calvet, F., Tucker, M. E., 1988. Outer ramp cycles in the Upper Muschelkalk of the Catalan Basin, northeast Spain. Sedimentary Geology, 57(3-4), 185-198.

Daoud, H.S., Balc, R. Sur, G.H., 2010. Microfossil assemblies and diagenesis of Balambo Formation from Mount Izmir in Northeast Sulaymaniyah, Kurdistan Region, Iraq. Iraqi Bulletin of Geology and Mining, 6(2), $1-16$.

Dunham, R. J.,1962. Classification of carbonate rocks according to depositional textures.

Embry, A.F., Klovan, J. E., 1971. A Late Devonian reef tract on northeastern Banks Island, NWT.

Flügel, E., 2010. Microfacies and archaeology in Microfacies of carbonate rocks. Springer, 903-915.

Gooday, A. J., Alve, E., 2001. Morphological and ecological parallels between sublittoral and abyssal foraminiferal species in the NE Atlantic: a comparison of Stainforthia fusiformis and Stainforthia sp. Progress in Oceanography, 50(1-4), 261-283.

Jassim, S. Z., Goff, J. C., 2006. Geology of Iraq. First edition. Prague and Moravian Museum, Brno, Czech Republic, 196-174

Kamikuri, S-I., Motoyama, I., Nishi, H., Iwai, M., 2009. Neogene radiolarian biostratigraphy and faunal evolution rates in the eastern equatorial Pacific ODP Sites 845 and 1241. Acta Palaeontologica Polonica, 54(4), 713-742.

Kennett, J. P., 1977. Cenozoic evolution of Antarctic glaciation, the circum-Antarctic Ocean, and their impact on global paleoceanography. Journal of Geophysical Research, 82(27), 3843-3860.

Kennett, J. P., Srinivasan, M. S., 1983. Neogene Planktonic Foraminifera: Hutchinson Ross, Stroudsburg, Pennsylvania.

Krasheninnikov, V. A., Hoskins, R. H.,1973. Late Cretaceous, Paleogene and Neogene Planktonic Foraminifera, assemblage, 200, 9.

Krasheninnikov, V. A., Plfaumann, U., 1978. Zonal Stratigraphy of Neogene Deposits of the Eastern Part of the Atlantic Ocean by Means of Planktonic Foraminifers. Leg 41, Deep Sea Drilling Project.

Mateu-Vicens, G., Pomar, L., Tropeano, M., 2008. Architectural complexity of a carbonate transgressive systems tract induced by basement physiography. Sedimentology, 55(6), 1815-1848.

Munnecke, A., and Servais, T., 2008. Paleozoic calcareous plankton: evidence from the Silurian of Gotland. Lethaia, 41(2), 185-194.

Scholle, P. A., Ulmer-Scholle, D. S., 2003. A Color Guide to the Petrography of Carbonate Rocks: Grains, Textures, Porosity, Diagenesis. American Association of Petroleum G Memoir 77. AAPG.

Servais, T., Munnecke, A., Versteegh, G. J. M., 2009. Silurian calcispheres (Calcitarcha) of Gotland (Sweden): comparisons with calcareous dinoflagellates. Comptes Rendus Palevol, 8(6), 527-534.

Sharland, P. R., Casey, D. M., Davies, R. B., Simmons, M. D., Sutcliffe, O. E., 2004. Arabian plate sequence stratigraphy-revisions to SP2. GeoArabia, 9(1), 199-214.

Sissakian, V., Al-Kubaisy, K., Al-Ansari, N., 2016. The Miocene Sequence in Iraq, a review and discussion on the stratigraphy, paleogeography and economic potential. Journal of Earth Sciences and Geotechnical Engineering, 6(3), 271-317.

Sissakian, V., Al-Jibouri, B. S. M., 2012. Stratigraphy of the low folded zone. Iraqi Bulletin of Geology and Mining, (5), 63-132.

Spezzaferri, S., El Kateb, A., Pisapia, C., Hallock, P., 2018. In situ observations of foraminiferal bleaching in the Maldives, Indian Ocean. Journal of Foraminiferal Research, 48(1), 75-84.

Wilson, J., 1975. Carbonate facies in geologic history. New York, Springer-Verlag.

Zachos, J. C., Opdyke, B. N., Quinn, T.M., Jones, C.E., Halliday, A.N., 1999. Early Cenozoic glaciation, Antarctic weathering, and seawater ${ }^{87} \mathrm{Sr} /{ }^{86} \mathrm{Sr}$ : Is there a link? Chemical Geology, 161(1-3), 165-180. 